\title{
Management Knowledge Assets: A Review of the Models Used to Measure and Report Intellectual Capital
}

\author{
Michael So ${ }^{\mathrm{a}}$ \\ ${ }^{a}$ United International College, Beijing Normal University and Hong \\ Kong Baptist University, China
}

\begin{abstract}
Contemporary organisations in both public and private sector are often examined not only in terms of their core functional business but also in how they have adapted to a knowledge-based and innovation-driven economy. As such, knowledge-based assets are considered as a source of sustainable advantage.

The magnitude of change in the proportion of value creation by these intangible investments has caused a paradigm shift and the recognition of an increasingly important role for intellectual capital (IC). There is also a growing interest in developing business reporting models that are more comprehensive than that of traditional accounting-based reporting, which has been shown to be inadequate to report the value of intellectual capital. Researchers and academics have attempted to build models for IC reporting. In this paper, eleven IC measurement models are critically reviewed and a framework of IC valuation and reporting based on capabilities is suggested. The capabilities enhanced by IC could be reported in combination with the tangible assets in an IC capability balance sheet. The IC capability model offers a clear starting point for a new thinking in evaluating intangible assets as a firm business resource.
\end{abstract}

Keywords: Intellectual Capital; Knowledge Assets; Valuation

\section{Introduction}

Intellectual capital (IC) is increasingly important in creating and maintaining competitive advantage and corporate value (Tayles et al., 2002). The expansion of the service sector, intense competition resulting from globalisation and deregulation, and the emergence of Information 
Technology (IT), have accelerated the shift towards a knowledge-based and innovation-driven economy (Bismuth \& Tojo, 2008).

The globalisation of the world economy and the increasing role of IT have also contributed to the growing demand for intellectual capital (Joshi, Singh Ubha \& Sidhu, 2010). The ability to make effective use of intellectual capital is thus a crucial factor that determines the success of a business in the modern knowledge-based economy (Goh, 2005).

Financial accounting reports are often criticised as missing important information that could better inform stakeholders of potential share market returns (Lee \& Guthrie, 2010). The growing distance between the market value and book value of firm is attributed to intangibles that cannot be properly measured and reported within the traditional accounting framework. Nevertheless, different IC models have been developed using a broad tray of approaches under various headings such as financial valuation, value measurement and measurement methods (Andriessen, 2004). These models for the assessment and measurement of IC are motivated by the drive to enhance business performance (Aho, Stahle \& Stahle, 2011).

The financial crisis of 2008 and its aftermath have led to renewed calls for reform of new reporting models for business (Singleton-Green \& Hodgkinson, 2009). In measuring and reporting of intellectual capital, Ratnatunga (2002) advised that managers should view intangibles as the "capabilities" of an organisation. He explained that intangibles could be perceived as a form of competitive advantage rather than as fixed assets. For example, an increase in training expenses could be treated as an enhancement in the capability of human assets (Ratnatunga, Gray \& Balachandran, 2004).

The aim of this paper is to provide an exploratory study for the understanding and measurement of IC and evaluate the strength and weakness of eleven existing IC measurement models. It examines a new valuation model based on IC capability value and a reporting framework comprising an intellectual capital capability (ICC) balance sheet.

This paper is structured as follows: The next section provides a background of the most relevant theoretical issues raised in relation to intellectual capital. It then deals with various definitions given by researchers to the concept of intellectual capital. The paper then provides a review of the capability approach based on the work of Ratnatunga, Gray and Balachandran (2004), followed with a discussion of eleven IC 
measurement models that have been developed under the headings of various valuation methods. Finally, it discusses and concludes with the new directions for the IC measurement and reporting.

\section{Theoretical Background}

\subsection{Stakeholders Theory}

The traditional view is that the fiduciary duty of management is to protect shareholders' interests. The stakeholder theory indicates that organisations are not only accountable to their shareholders but should make decisions for the benefit of all stakeholders (Freeman, 1984). It also emphasises the importance of relationships the firm needs to create with their stakeholders (Freeman, Wicks \& Parmar, 2004).

Value is created based on the integration of the relationships and interests of groups of stakeholders in a way that guarantees the ongoing success of the organisation (McVea \& Freeman, 2005). Under stakeholder theory, the economic value created by the business system is no longer being regarded as belonging exclusively to its financiers (i.e. shareholders and debt holders) but should be shared by various stakeholders (Deegan, 2000).

Stakeholder theory reflects a concept of accountability that is broader than just stewardship of shareholder interests. The theory suggests that all stakeholders have a right to be provided with information about how organisational activities impact upon them (Deegan \& Gordon, 1996).

Stakeholder theory could be used to explain how the companies measure and report their IC to serve and coordinate the interests of its various stakeholders. From this perspective, the firm' continued existence requires the support of stakeholders and their approval must be sought. Activities of the firm need to be adjusted to gain that approval (Gray, Kouhy \& Lavers, 1995). The theory further purports that management will engage in activities that are expected by the firm's stakeholders (Guthrie et al., 2004) and that stakeholders have a right to be provided with information about how the firm's activities affect them (Vergauwen $\&$ van Alem, 2005). IC measurement and reporting are thus seen as parts of the dialogue between the company and its stakeholders and are relatively important mediums for improving relationships between them (An, Davey \& Eggleton, 2011). As such, stakeholders require 
information about important intangible assets and IC (Whiting \& Miller, 2008).

\subsection{Resource-based Theory}

According to the resource-based theory, there are two sources of competitive advantage: assets and capabilities (Day, 1994). According to Day (1994), assets are the resources accumulated and capabilities can bind the different resources together to enable firms to create superior financial performance. Both assets and capability create shareholder value by enhancing cash flows and reducing the volatility of cash flows (Day \& Fahey, 1988; Luo \& Donthu, 2006). Based on this argument, Day and Fahey (1988) find that the efficient management of a firm's IC can in the long run lead to improved shareholder value. In a knowledge-based economy, the intangible capability is an important source of competitive advantage because it combines with other resources to enhance value of an organisation (Ratnatunga, 2002).

It is difficult to visualise intangible assets and capabilities and it is harder to communicate their value to stakeholders (Yang, Brashear \& Asare, 2015). Although IC may not be visible, they can still be measured and managed (Ratnatunga, 2002).

When formulating a corporate strategy, firms not only have to assess their opportunities and threats but also to identify their resources to develop their competence (Marr, Gray \& Neely, 2003). This means that IC should be one of the important considerations in formulating strategy and one of the key sources of firm's profitability and cash flows (Grant, 1991). In this context, firms are required to strategically identify and develop their IC to gain a competitive advantage and to enhance their performance (Teece, Pisano \& Shuen, 1997). Thus, the key to a resourcebased approach to strategy formulation is to identify and measure the IC of a firm (Marr, Gray \& Neely, 2003). IC measurement models could provide actionable insight on management resource-allocation decisions (Yang, Brashear \& Asare, 2015).

\subsection{Intellectual Capital Definitions}

It is difficult to provide a unified definition and accepted typology for IC (Martin-de-Castro et al., 2011) as different definitions are associated 
with different approaches. However, most IC definitions include a common element, intangible assets (MERITUM, 2002).

An important characteristic of IC is its intangible nature. Intellectual capital is a hidden asset that does not exist in physical form but holds value and can generate competitive advantage to the organisation (Choong, 2008). It represents the set of intangibles that are susceptible of being recognised as assets in accordance with the perspective of financial accounting (MERITUM, 2002). Martin-de-Castro et al. (2011), however, treat IC as a synonym for intangible or knowledge assets. They consider IC as a capital because it could be regarded as a process of value creation.

From a strategic point of view, IC is regarded as the strategic assets of a firm with key characteristics of rarity, inimitability and nonsubstitutability (Riahi-Belkaoui, 2003). It is a crucial success factor for a firm's long-term profit and performance in a knowledge-based economy (Hsu and Fang, 2009; Kong, 2010). Using a different approach, Mouritsen (2006) defines IC in a performative manner whereby the concept of IC is situation dependent. The meaning of IC could only be known in relation to specific instances of interaction. In this regard, IC is a representation of knowledge resources whose transformative qualities emerge in application (Mouritsen, 2006, p. 824).

Later intellectual capital definitions have developed into three categories: Human capital, structural capital and relational capital (Abeysekera \& Guthrie, 2004, 2005; Bozzolan, Favotto \& Ricceri, 2003; Brennan, 2001; Martin-de-Castro et al., 2011; Sveiby, 1997). A consensus seems to be emerged whereby IC can be divided into three major components: human skills and expertise, internal organisational structure, and external structure. In an attempt to focus on competitive advantage, Ratnatunga (2002) views IC as a source of organisation's capabilities, rather than as an asset in a static approach.

\section{The IC Capability Model: A New Direction for Measuring IC}

Literature on the IC capability model offers a number of intellectual capital measurements as outlined in the eleven IC measurement models covered in next sections of the present study. A neglected area of valuation is how firm value can be enhanced via the targeted expenditure on certain aspects of IC. 
In the corporate world, investors and managers are becoming increasingly aware of the value of intangible assets and how all their assets, both tangible and intangible, combine to produce the capability to lift their firm's economic value.

With a view to developing a consistent framework for valuing and reporting IC that caters for the needs of all the interested stakeholders, a model built on the Capability Economic Value of Intangible and Tangible Assets (CEVITA) approach was proposed by Ratnatunga, Gray and Balachandran (2004) to consider the capability of intellectual capital. A 'Capability' is what can be achieved when assets are combined in a contextual situation, and the capability value is the economic value of the capability (Ratnatunga, Gray and Balachandran, 2004).

The capability approach is consisted of a univariate capability model to value a IC capability at a point in time based on past investments on IC and a multivariate model that incorporates specified IC variables (as antecedents) for Intellectual Capital Capability (ICC) enhancement. This approach enables the estimation of expenditure required to either enhance or maintain such a value.

Expenditure to build ICC is particularly amenable to IC valuation. Ratnatunga, Gray, and Balachandran (2004) and Ratnatunga and Ewing (2005) suggest that there is a strong and demonstrable link between what an organisation spends in a particular period on a capability, and how such an expenditure can increase (or if the spend is inadequate, decrease) the capability's value. Such a valuation approach is no different to the traditional revaluation of a non-current asset, which will be dependent on the extent of money expended to increase or maintain its capability. Accordingly, Ratnatunga, Gray, and Balachandran (2004) reason that by using specific Expense Leveraged Value Indices (ELVI), to calculate the capability economic values for all tangible and intangible assets in a firm. For example, based on ELVI, managers can estimate how much IC capability could be leveraged up by spending a certain amount of training expenses.

As companies would need to possess an understanding of which IC is value for the organisation, the IC capability approach will provide a basis for organisation-specific refinement and application (Ratnatunga, Gray \& Balachandran, 2004). In practice, IC resources are very diverse and specific to particular organisations. Thus, there needs to be an integration of various IC strengths that constitute the value-enhancing efforts 
required to enhance ICC value. Managers need to identify their firms' IC strength factors that could enhance the IC capability.

By applying the multivariate analysis of ELVI in determining the value of IC capability, managers are required to justify the proportion of funds expended on each IC strength factor of their organisations. It can be posited that the expenses targeted to enhance the IC strength factors can potentially have both an attitudinal effect in terms of the recognition and the perceived quality of ICC, and a behavioural effect on sales.

To develop a holistic view of the value of a business system, an ICC balance sheet is recommended by So (2014) for recognition of capabilityenhancing assets. The ICC balance sheet has no direct connection with the book value. It is a way of expressing the composition of the market value of assets and liabilities. More precisely, the asset side displays the market value of all the resources contributing to the company development, including those intangible assets which are not directly controlled by the company, such as capabilities and trust it shares with managers, employees, customers, and suppliers. The equity side represents the shares capital, reserves and intellectual capital. This approach not only presents a comprehensive picture of the value-creating resources but also emphasises the dynamic flows of the resources of an organisation.

\subsection{Reviewing IC Measurement Models}

It is often argued that measurement can lead to better management. Stewart (2001, p. 291) believed that 'you cannot manage what you cannot measure'. Mouritsen, Bukh and Marr (2004) pointed out that measurement of IC was not a passive act of recording. It helped to develop the knowledge in its strategic progress and initiate follow up actions. Therefore, it is necessary to develop measures of intangible resources. Intangibles such as copyrights, brand, and trade names face less measurement problems because they can be bought and sold. Nonetheless, other intangibles like human capital, structural or relational capital vary along with the ability of the firm to sell them, which make their measurement more difficult.

Andriessen (2004) developed a theoretical framework to classify various IC measurement methods under three headings of financial valuation, value measurement and measurement (Figure 1). He pointed out that financial valuation took the advantage of using money as the 
denominator of value because it allowed for mathematical transformations. Sveiby (2010) added that financial valuation could be used for demonstrating the financial value of IC and communicated in the accounting profession. Moreover, financial value can also be used for comparisons between companies in the same industry.

Figure 1. Framework for discriminating between different types of IC assessment

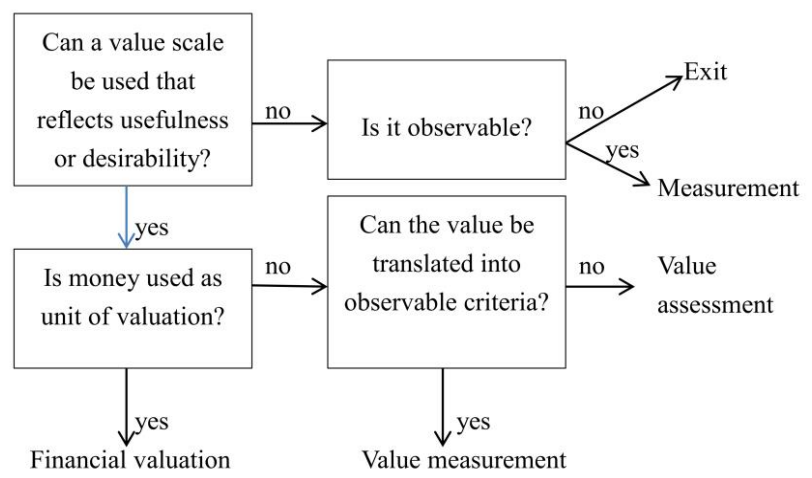

Source: Andriessen (2004)

Measurement is the process of assigning scaled numbers to items in such a way that the relationships between the possible states of a variable are reflected in the relationships between the numbers on the scale (Andriessen, 2004). According to Andriessen (2004), a value measurement method measures items in non-monetary term and translates them into observable phenomena. It contains norms to act as yardsticks of value. On the other hand, a measurement method which does not include a criterion for value but involves a metric scale that relates to observable phenomenon. Such method does not use values, norms, or other yardsticks and it cannot be considered as a valuation (Andriessen, 2004).

Sveiby (2010) claimed that the value measurement method and the measurement method could give a more comprehensive picture of a company. This study discussed eleven IC measurement methods based on the classifications adopted from Andriessen (2004) and Sveiby (2010), as indicated in Table 1. There are four models using financial valuation 
method, three models in value measurement and four models using measurement method.

Table 1. Classification of IC measurement methods

\begin{tabular}{|c|c|c|}
\hline Financial Valuation & Value Measurement & Measurement \\
\hline $\begin{array}{l}\text { Market-to-book value } \\
\text { (Stewart, 1997) }\end{array}$ & VAIC (Pulic, 1998, 2000) & $\begin{array}{l}\text { Skandia navigator } \\
\text { (Edvinsson \& Malone, } \\
\text { 1997) }\end{array}$ \\
\hline Tobin’s Q (Stewart, 1997) & $\begin{array}{l}\text { Intellectual capital audit } \\
\text { (Brooking, 1996) }\end{array}$ & $\begin{array}{l}\text { Intangible asset monitor } \\
\text { (Sveiby, 1997) }\end{array}$ \\
\hline $\begin{array}{l}\text { Economic value }{ }^{\mathrm{TM}} \text { (Stern, } \\
\text { Stewart \& Chew, 1995) }\end{array}$ & $\begin{array}{l}\text { Balanced Scorecard } \\
\text { (Kaplan \& Norton, 1992; } \\
\text { 1996; 2001) }\end{array}$ & $\begin{array}{l}\text { MERITUM guidelines } \\
\text { (MERITUM, 2002) }\end{array}$ \\
\hline $\begin{array}{l}\text { Calculated intangible } \\
\text { value (Stewart, 1997) }\end{array}$ & & $\begin{array}{l}\text { Danish guidelines } \\
\text { (Mouritsen et al., 2003) }\end{array}$ \\
\hline
\end{tabular}

\subsection{Financial Valuation Method}

IC valuation requires a framework for the valuation, and a criterion that reflects the usefulness or desirability of the object. The financial valuation method defines the criterion of value in monetary terms (Andriessen, 2004). Four out of eleven models can be labelled as a financial valuation method. The financial valuation models use money as unit of value. However, these models do not immediately identify the components of IC and does not easily assist managers to understand the dynamics of a business (Andriessen, 2004; Bontis, 2001; Guthrie, Petty \& Johanson, 2001).

Market-to-book value is often defined as the difference between market and book value of a business (Edvinsson \& Malone, 1997). Tobin's Q is the ratio between the market value and replacement value of the same physical asset (Luthy, 1998). Economic Value Added (EVA) is an analytic tool for measuring a company's performance in term of economic profit (Stern, Steward \& Chew, 1995), whereas calculated intangible value (CIV) says that intellectual capital is the portion of a company's profits exceeding average return prevailing in the industry (Steward, 1997). 


\subsubsection{Market-to-Book Value}

This is the value-based measures of intellectual capital (Brennan, 2001). It is argued that the difference between market value of equity and the book value of assets reported in the balance sheet can be associated with the IC value (Edvinsson, 2000; Edvinsson \& Malone, 1997).

Brennan and Connell (2000) questioned the usefulness of this figure because it is just a singular measure of IC value and does not give a detail of the IC components. Additionally, it is not appropriate to conclude that the difference between the market value of the firm and its book value of equity is entirely derived from the existence of intangibles not reflected by the accounting principles (Garcia-Ayuso, 2003). Firstly, stock prices may not always be considered as unbiased estimates of the market value of firms. Secondly, the calculation of book value is also dependent on accounting standards. This causes a questionable consequence that the value of IC will change with the changes in accounting method (Mouritsen, Larsen \& Bukh, 2001).

\subsubsection{Tobin's $Q$}

Tobin (1969) introduced Q ratio and argued that the capital investment in a firm would be dependent on the ratio between stock market valuation of capital assets and their current replacement cost. The $\mathrm{Q}$ is the ratio of the market value of companies' equity to the replacement cost of their assets which is assumed to be the book value of the firm (Luthy 1998). Sennetti, Kim and Sellani (2004) claimed that if the market value of a firm's assets is higher than the replacement cost of its assets, then a company is getting higher than normal returns on their investment (i.e. intangibles). The market capitalisation and intangible value is related, so a high value of Tobin's Q would show a higher value of the intangibles (Sahay \& Pillai, 2009).

The ratio is a forward-looking measure, indicating market-based views of investor expectations of the firm's future profit potential (Sahay \& Pillai, 2009). Stewart (1997) specified that Tobin's Q is not intended to be a measure of IC but it can be a good indicator of IC. High Q could represent that the firm is gaining extraordinary profit on a class of assets and not experiencing diminishing returns. However, Tobin's Q ratio is subjected to problems of internal validity and should be used when making comparisons of the value among firms within the same industry and across the same periods (Sennetti, Kim \& Sellani, 2004). 


\subsubsection{Economic Value Added}

Stern, Stewart and Chew (1995) suggested EVA is an indicator to evaluate organisation performance in term of economic profit. This method is not specifically designed to measure the value of intangibles. It is the result of subtracting the opportunity cost of invested capital from the net operating profit after tax. The opportunity cost can be determined by multiplying the weighted average cost of debt and equity capital by the amount of capital employed.

The EVA is intended to be a reasonable measure for evaluating the performance of the whole business; it may be established by the following equation as stated in Bontis (2001):

EVA $=$ Net sales - operating expenses - taxes - opportunity cost of invested capital

Although EVA might be used as a proxy for IC measurement, Andriessen (2004) questioned the reasonableness of this indicator in measuring the value added of intangible resources. This is because the value gained by a company will be contributed by both the tangible and intangible resources. IC alone may not function without the support of tangible assets such as machinery and financial capital.

\subsubsection{Calculated Intangible Value}

CIV measures the company's excess over the industry's average return on operating assets (Sennetti, Kim \& Sellani, 2004). It asks what investors are willing to pay as a given income instream in the future (Sennetti, Kim \& Sellani, 2004). This method assumes that a company's premium earnings are the result of intellectual capital. It is a measure to determine the fair market value of intangible asset of a firm (Stewart, 1997).

CIV is often used by the Inland Revenue Service in the US for tax purposes (Stewart, 1997). The CIV measurement method also provides a statutory and transactional motive of financing securitisation (Andriessen, 2004, p. 236). The method allows financial institutions to make an independent appraisal of IC in granting loan commitments. However, the CIV model assumes that a company's after-tax return is a result of its 
intellectual capital. There are in fact many factors that contradict this assumption (Aho, Stahle \& Stahle, 2011). In practice, the level of excess return is also influenced by other factors, such as the operating environment, the financial position and market structure of a firm (Aho, Stahle \& Stahle, 2011).

\subsection{Value Measurement Method}

The value measurement method uses a range of indicators that have yardsticks attached that represent the optimal state of the indicator (Andriessen, 2004). The intangibles being measured relates to a value but is measured in non-monetary terms. Three IC measurement models are categorised as value measurement method. They group financial and nonfinancial indicators and accompanying norms into different perspectives. Value added intellectual coefficient (VAIC) explains the efficiency of physical and financial capital, human capital, and structural capital (Chen, Cheng \& Hwang, 2005). Intellectual capital audit uses a range of indicators that measures market assets, intellectual property, human assets and infrastructure (Brooking, 1996). The Balanced Scorecard (BSC) includes indicators to measure an organisation with four perspectives: financial, customers, internal business processes, and learning and growth (Kaplan \& Norton, 1993).

\subsubsection{Value Added Intellectual Coefficient}

VAIC is considered a 'universal indicator showing the intellectual abilities of a company in value creation and representing a measure for business efficiency in a knowledge-based economy' (Pulic, 1998, p. 9). Given the emphasis of employees in value creation, Pulic (1998) used VAIC as a measure of intellectual capital.

The major components of VAIC can be viewed from a resource base of a firm: physical and financial capital, human capital, and structural capital. Instead of directly valuing the IC of a firm, the VAIC method mainly measures the efficiency of these three capitals, which sum up the value of VAIC (Chen, Cheng \& Hwang, 2005). The VAIC is defined as a composite sum of three separate indicators: 
$\mathrm{VAIC}=\mathrm{CEE}+\mathrm{HCE}+\mathrm{SCE}$

Where:

Capital employed efficiency (CEE): indicator of value added efficiency (VA) of capital employed $=$ VA $/$ CE.

Human capital efficiency (HCE): indicator of value added efficiency (VA) of human capital $=$ VA $/$ HC.

Structural capital efficiency (SCE): indicator of value added efficiency (VA) of structural capital = SC / VA.

Value added efficiency $(\mathrm{VA})=$ interest expenses + depreciation + dividends + corporate taxes + retained profit for the year.

Capital employed $(\mathrm{CE})=$ book value of net assets

$\mathrm{HC}=$ total expenditures on employees; $\mathrm{SC}=\mathrm{VA}-\mathrm{HC}$

Iazzolino and Laise (2013) agreed that VAIC is an effective measure of IC because it not only placed an emphasis on the value of employees but also linked to key success processes. VAIC is designed to monitor and evaluate the efficiency of value added by a firm's total resources (Pulic, 2000). It refers to the total value creation efficiency due to both IC and physical capital functioning in the company (Pulic, 2004). The basic assumption is that IC alone cannot operate independently without the support of financial and physical capital (Seetharaman, Low \& Saravannan, 2004; Tseng \& Goo 2005).

Recently, it is argued that VAIC parameters have nothing to do with intellectual capital; it merely describes the overall efficiency by combining the labour productivity and capital productivity (Stahle, Stahle \& Aho, 2011). Moreover, Stahle, Stahle and Aho (2011) illustrated that VAIC should solely be used as the concepts of labour productivity and returns on capital.

\subsubsection{Intellectual Capital Audit}

This method was developed by Annie Brooking, the founder of Technology Broker. Brooking (1996) broke down IC into four categories: market assets, intellectual property assets, human-centred assets, and 
infrastructure. She then developed several audit questions for each component of IC. The process of IC audit is supposed to discover potential strengths and weaknesses of IC in the organisation. Based on the audit process, IC components are identified and obtained from questionnaires and are assigned a direct value. The main weakness of this approach lies in the subjective nature in the process of converting the qualitative results of audit questionnaire into an IC value (Bontis, 2001).

\subsubsection{Balanced Scorecard}

Kaplan and Norton (1993) suggested BSC offers four distinct views of organisation with four perspectives: financial, customers, internal business processes, and learning and growth, and measures could be developed for each of the four perspectives.

BSC attempts to broaden the focus of managers by encouraging them to look beyond financial information and towards intangible items. BSC translates strategy and vision into objectives and measurable targets. In this way, it serves as a communication channel within an organisation, rather than simply a means of periodic reporting (Roslender \& Fincham, 2001).

Kaplan and Norton (2001) pointed out that BSC is a framework that links tangible and intangible assets. The financial perspective looks to traditional accounting measures such as profitability, risk and growth. The customer perspective includes indicators that measure the relationship that an organisation has established with its desired customers. The internal business processes perspective is concerned with the methods and practices used inside an organisation to create value and how these processes can be enhanced. The learning and growth perspective is focused on priorities to create an environment that is conducive to organisational change, innovation and growth. Overall, their aim is to complement financial measures of performance to create a balanced view of results of management actions (Andriessen, 2004). The BSC can assist the IC measurement, and the four perspectives could potentially improve the management of IC (Wu, 2005).

Nevertheless, unlike other measurement models (e.g. Skandia value scheme and intangible asset monitor), BSC tends to focus more on customer capital, and only provide incidental information on human capital (Petty \& Guthrie, 2000). Johanson et al. (2006) also argued that the implementation of BSC could create dilemmas. BSC is supposed to 
emphasise management control and non-financial indicators. However, goals initiated from the top often fail to encourage employees' intelligibility and productivity. Although BSC was primarily about management and internal reporting, Kaplan and Norton (1996) suggested that the company would gain benefits if BSC information could be communicated to outsiders; yet few firms refer to BSC in their external reporting (Singleton-Green \& Hodgkinson, 2009).

\subsection{Measurement Method}

The measurement method is to interpret the mechanism by which drivers contribute to the value creation and to explain how knowledge assets are assembled and which manner they interact to enhance organisation's value. Although these frameworks can display classifications of components of IC and show a more comprehensive picture of an organisation, they do not require the assignment of a value to the IC components (Grimaldi, Cricelli \& Rogo, 2013). As a result, they may not readily be accepted by managers who are only familiar with pure financial perspective (Sveiby, 2001). Moreover, the value drivers of a company are very specific and it is difficult to make comparisons between companies (Grimaldi, Cricelli \& Rogo, 2013).

Four measurement frameworks have been developed. Skandia Navigator analysed IC up to five components: human resources, processes, renewal and development, operating environment as well as financial (Edvinsson \& Malone, 1997). Intangible Asset Monitor (IAM) measure three aspects of intangibles: employee competence, internal capital and external capital (Sveiby, 1997). MERITUM guidelines (2002) propose an IC statement and assess intangible resources into three classes: human capital, structural capital and relational capital, whereas Danish guidelines describe an IC statement by four knowledge resources: employee, customers, processes and technologies (Mouritsen et al., 2003).

\subsubsection{Skandia Navigator}

Edvinsson (1997) developed a reporting format of non-financial items that emerged as the Skandia Navigator. The Skandia Navigator offers a conceptual understanding of viewing the relationship between IC and financial capital in determining the market value of the firm. It serves to measure and account for both the tangible and intangible assets of an 
organisation. Most importantly, Skandia Navigator can be used to identify and quantify critical success factors of a business (Brennan, 2001).

The Skandia Navigator also provides a founding taxonomy that identifies the various elements of IC. The Navigator is designed to provide information on the human resources and processes, renewal and development foci of the organisation, operating environment, as well as financial information (Edvinsson \& Malone, 1997). It is normally used for performance appraisal and rewards assessment. Instead of valuing various IC components, Skandia Navigator developed a set of indicators designed to represent the growth of IC over a period of time (Roslender $\&$ Stevenson, 2009).

Within the Skandia value system, IC is the balancing item as being the difference between market value and financial capital; whereas the value of IC is the sum of human capital and structural capital (Edvinsson, 1997). This summary gives the balanced overview between the financial and non-financial dimensions and provides an accounting language for the sustainability of the organisation (Edvinsson, 1997).

Unfortunately, such a hidden value perspective has made limited progress. Firstly, Skandia Navigator is based on a linear, additive value creation model. But value creation association could be multiplicative, and neither linear nor additive in nature (Kaplan \& Norton, 2001). Furthermore, IC is the sustainable competitive advantage of the organisation; As such, the provision of IC information should be emphasised on current and future activities, rather than the historical approach of incorporating the value of IC in the balance sheet (Fincham \& Roslender, 2003).

\subsubsection{Intangible Asset Monitor}

Sveiby (1997) introduces IAM, which included non-financial categories of employee competence, internal capital and external capital. Employee competence includes education and training of the professional staff who are the principal generators of revenue. Internal capital includes the organisational structure, legal parameters, manual systems, research and developments, and software. External capital includes brands, and customer and supplier relationships. Sveiby (1997) measured each of the three intangibles by identifying three measurement indicators: growth and renewal, efficiency (management information), and stability (external 
accounts). He also suggested a few variables indicative of each indicator; therefore, the information displayed in IAM was intended to serve both the managers and external stakeholders (Sveiby 1997). Within this framework, a full picture of shareholder value can be provided through the non-financial measures to measure intangibles, as well as the financial measures to measure book value of equity (Bontis, 2001).

Similar to the balanced scorecard, IAM is designed to report on qualitative IC information and to present an account of company performance and future potential (Sveiby, 1997). Classifying IC into three components, IAM shows how this IC wealth is enhanced or diminished from one period to the next. It is found that the IAM views employees and their competencies as the most important asset and this is a significant departure from traditional accounting with a focus on only those acquired intangibles (Cuganesan \& Petty, 2010).

\subsubsection{MERITUM Guidelines}

The MERITUM guidelines (MERITUM, 2002) were developed by researchers from six European countries, a steering committee, and some other supporting institutions through funding provided by the European Union Commission. The guidelines have been widely accepted by firms and have a strong institutional and corporate support (Bukh \& Johanson, 2003).

The MERITUM guidelines (MERITUM, 2002, p. 9) define intangibles as non-monetary sources of probable future economic benefits that lack physical substance, are controlled as a result of past transactions and events. They may or may not be separable. The guidelines suggest that IC has three main categories: human capital (knowledge that employees take with them when they leave the firm), structural capital (knowledge that stays with the firms at the end of the working day, such as organisational routines, procedures, systems, cultures, databases, etc.), and relational capital (resources linked to the external relationships of the firm, with customers, suppliers, etc.).

The guidelines suggest an IC statement with three clearly differentiated parts: the vision of the company, a summary of resources and intangible activities, and a system of indicators (Palacios \& Galvan, 2007). 
To indicate how a company can reach its strategy and how it creates value for itself and the stakeholders, the points of connection between resources and critical activities are suggested in an IC statement (Palacios \& Galvan, 2007). Nevertheless, IC statements only disclose aspects of the knowledge-management activities but not the IC values (Bukh, Larsen \& Mouritsen, 1999). It is preferable if IC statements have quantification to signify financial implications of the object of knowledge management (Mouritsen et al., 2002).

\subsubsection{Danish Guidelines}

The Danish guidelines (Mouritsen et al., 2003) were authorised by a task force financed by the Danish government. The guidelines describe how to prepare an IC statement in practice and proceed with providing some practical guidelines on the preparation of IC statements.

The guidelines describe that an IC statement is an integral part of knowledge management within a company. The guidelines propose an approach of knowledge resources of four types, related to employees, customers, processes and technologies (Mouritsen, 2003)

The Danish guidelines mention that an IC statement consists of four levels: a knowledge narrative, a set of management challenges, a set of initiatives, and a set of indicators. The knowledge narrative expresses how the products and services of the organisation provide value to the user. Management challenges include existing knowledge resources that should be strengthened and new knowledge resources that are required. Each management challenge is made up of a number of initiates, which are actions concerned with how to develop or obtain knowledge resources and how to monitor them. Lastly, indicators are the measures of the initiatives that make it possible to assess whether initiatives have been implemented and whether they achieve the desired effect. The Danish guidelines consider knowledge in action and in a more practical sense (Palacios \& Galvan, 2007). Together, these four elements are interrelated and represent the evaluation of IC of the organisation (Mouritsen, Bukh \& Marr, 2004).

The IC statements comprise developing detailed actions attached to management challenges, as well as specific indicators to measure the impact of the actions. With respect to the classifications of these actions and indicators, the guidelines recommend a flexible approach of classification. From the viewpoint of Danish guidelines, an IC statement 
is not just a strategic tool for adding value to an organisation, but also a communication tool that involve client, employees and other users in the process (Palacios \& Galvan, 2007). However, the main challenge of implying the guidelines is to identify those key factors that have significant impact on organisation performance (Grimaldi, Cricelli \& Rogo, 2013). Moreover, during implementation, Nielsen et al. (2006) illustrated that the classification of indicators was sometimes difficult and could involve a number of decision rules.

\section{Moving Towards IC Capability Model and ICC Balance Sheet}

IC has become an important source of sustainable competitive advantage and IC information is useful in assisting management decisions. The reporting of IC is a popular notion whereby it could improve the management of intangible resources (Andriessen, 2004). However, the differences among the measurement methods and the subsequent lack of comparability have been identified as the main barriers that limit the current impact of IC reporting in capital markets (Bukh, 2003; Garcia-Ayuso, 2003). Firms offering IC measurement provide their own tools and these appear to have different purposes for measurement.

The financial valuation method is appropriate for illustrating IC by money term, but the IC value is of limited use for management purpose (Sveiby, 2010). On the other hand, the value measurement and the measurement method tend to contain a number of IC indicators and has been too firm-specific (Bontis, 2001). Besides this, some measure IC which has no obvious connection to financial performance (Ratnatunga, 2002).

While there are many new measurement systems using measures of human capital, customer relationships and brand values, there are significant downsides in such measurements. Many of these new systems appear elegant but would require large investments in data collection.

All of the above measures have strengths and weaknesses in the valuing IC of an organisation. To satisfy various stakeholders' needs, the International Accounting Standards Committee faces a challenge in setting standards for IC disclosure (Bontis, 2001). Furthermore, consistent norms and principles for intellectual capital measuring and reporting become a new challenge for managers (Campos \& Pablos, 2007). Accordingly, researchers and policy makers are challenged to 
develop an IC measurement model that involves relating both tangible and intangible information in a single document but is likely to represent the diverse elements of an organisation (Eccles \& Serafeim, 2011).

Recently, new performance measurement systems have been made to value the capability of specific IC of a firm using financial values (Ratnatunga, 2002). The ICC measure, presented via ICC balance sheet, provides a very useful and practical way to visualise and value the intangible capability assets of an organisation. Moreover, unlike other financial valuation models, the capability approach supports specificity of the IC component of an organisation.

Two theories (Resource-based theory and stakeholder theory) related to IC disclosures hold some attractiveness for explaining the capability approach. Resource-based theory is based on the idea of value creation with the manager's ability to leverage total resources of the organisation (Marr, Gray \& Neely, 2003). The IC capability model suggested a framework of valuing IC that could be employed to satisfy the specificity of IC drivers of an organisation. Additionally, it could explain how IC capability could be enhanced via the targeted expenditure on certain aspects of IC (Ratnatunga, Gray \& Balachandran, 2004). Costs incurred in investing in each IC strength is compared with benefits in term of revenue potential that is due to an enhanced IC capability value. This approach can help managers improve strategic thinking by identifying IC strength drivers of corporate value, and requires managers participate directly in assessing and managing the value creation process.

With budgetary constraints, the IC capability model requires managers to identify the IC strength components and their relationships with their funding, and to facilitate more effective managerial interventions to the achievement of the value enhancement.

Moreover, the IC capability model takes the view that both the tangible resources and the capability-enhancing intangible resources are reported on an ICC balance sheet. The ICC balance sheet will incorporate the traditional financial information as a measure of success and as a resource for investment, but the focus will be on measuring the capability-enhancing intangible assets, and the corresponding intellectual capital. It reports on firms' competence and resource-based strategies.

According to stakeholder theory, the presence of intangible assets modifies the allocation of residual claims as company performance can substantially affect the wealth of those stakeholders embodying some of 
the critical factors for company success. Obviously, the economic value created by the company is no longer being regarded as belonging exclusively to its financiers (Deegan, 2000), but should be shared by various stakeholders. The ICC balance sheet is a way of expressing the composition of the market value of assets and liabilities. More precisely, the asset side displays the market value of all the resources contributing to the company development, including those intangible assets, such as capabilities and trust it shares with managers, employees, customers, and suppliers. Rather than focusing primarily on shareholders, the report of IC challenges managers to examine more broadly the value their firms are creating from the perspective of the stakeholders who are involved in creating it.

\section{Concluding Remarks}

Intellectual capital measurement is a fast-growing part of the knowledge management market. The eleven IC models used to measure IC are not mutually exclusive. Some are designed to help investors assess the intangible resources, while some are designed to give managers a more comprehensive picture of how a company create value for its stakeholders.

To view IC as an organisation's capabilities, the Capability Economic Value of Intangible and Tangible Assets (CEVITA) approach (Ratnatunga, Gray \& Balachandran, 2004) can be adapted and applied to the valuation of intellectual capital capability. This model could cater for the diverse elements of the specificity of an organisation, but at the same time, provide a valuation for ICC.

As they currently stand, ICC measure are less useful in putting a reliable valuation on intangible assets for outside investors who lack the knowledge to generate the required ELVIs. However, even if business analysts using their own ELVIs attempted an externally generated valuation, the resultant ICC measure would provide a more comprehensive approach to the valuation of an organisation's assets than the measures currently available, as it incorporates all key strengths of many of those numerous valuation measures.

Apart from the IC capability valuation, it is also important to devise a strategic balance sheet to incorporate IC into financial statements (Ratnatunga, Gray \& Balachandran, 2004). The ICC balance sheet enables managers to present a comprehensive picture of company's 
Management Accounting Frontiers 1 (2018) 15 - 44

resources and show how IC expenditures can enhance the value of a company. It can improve the visualisation of both the tangible and intangible resources of the company so that they can be managed comprehensively. 


\section{References}

Abeysekera, I. and Guthrie, J., (2004), "Human Capital Reporting in a Developing Nation". British Accounting Review, Vol. 36 No. 3, pp. 251268.

Abeysekera, I. and Guthrie, J., (2005), “An Empirical Investigation of Annual Reporting Trends of Intellectual Capital in Sri Lanka", Critical Perspectives on Accounting, Vol. 16 No. 3, pp. 151-163.

Aho, S., Stahle, S. and Stahle, P., (2011), "A Critical Assessment of Stewart's CIV Method", Measuring Business Excellence, Vol. 15 No.4, pp. 27-35.

An, Y., Davey, H. and Eggleton, I., (2011), "Towards a Comprehensive Theoretical Framework for Voluntary IC Disclosure", Journal of Intellectual Capital, Vol. 12 No. 4, pp.571-586.

Andriessen, D., (2004), "IC Valuation and Measurement: Classifying the State of the Art", Journal of Intellectual Capital, Vol. 5 No. 2, pp. 230242.

Bismuth, A. and Tojo, Y., (2008), "Creating Value from Intellectual Assets", Journal of Intellectual Capital, Vol. 9 No. 2, pp. 228-245.

Bontis, N., (2001), "Assessing Knowledge Assets: A Review of the Models Used to Measure Intellectual Capital", International Journal of Management Review, Vol. 3 No. 1, pp. 41-60.

Bozzolan, S., Favotto, F. and Ricceri, F., (2003), "Italian Annual Intellectual Capital Disclosure: An Empirical Disclosure", Journal of Intellectual Capital, Vol. 4 No.4, pp. 543-558.

Brennan, N., (2001), "Reporting Intellectual Capital in Annual Reports: Evidence from Ireland", Accounting, Auditing and Accountability Journal, Vol. 14 No. 4, pp. 423-436.

Brennan, N. and Connell, B., (2000), "Intellectual Capital: Current Issues and Policy Implications", Journal of Intellectual Capital, Vol. 1 No. 3, pp. 206-240.

Brooking, A., (1996), Intellectual Capital: Core Assets for the Third Millennium, International Thomas Business, London.

Bukh, P. N., (2003), "The Relevance of Intellectual Capital Disclosure: A Paradox?", Accounting, Auditing and Accountability Journal, Vol. 16 No.1, pp. 49-56. 
Bukh, P. N. and Johanson, U., (2003), "Research and Knowledge Interaction: Guidelines for Intellectual Capital Reporting", Journal of Intellectual Capital, Vol. 4 No.4, pp. 576-587.

Bukh, P. N., Larsen, H. T. and Mouritsen, J., (1999), "Constructing Intellectual Capital Statements", Scandinavian Journal of Management, Vol. 17 No.1, pp.87-108.

Chen, M. C., Cheng, S. J. and Hwang, Y., (2005), "An Empirical Investigation of the Relationship between Intellectual Capital and Firm's Market Value and Financial Performance", Journal of Intellectual Capital, Vol. 6 No. 2, pp. 159-176.

Choong, K. K., (2008), "Intellectual Capital: Definitions, Categorization and Reporting Models", Journal of Intellectual Capital, Vol. 9 No. 4, pp. 609-638.

Campos, E. B. and Pablos, P. O., (2007), "The Intellectual Capital Statement: New Challenges for Managers", in L. Edvinsson (ed.), Strategies for Information Technology and Intellectual Capital: Challenges and Opportunities, IGI, Hershey, pp.91-109.

Cuganesan, S. and Petty, R., (2010), "Intellectual Capital Measurement and Reporting: Issues and Challenges for Multinational Organisations", in K. O'Sullivan, Strategic Intellectual Capital Management in Multinational Organisations: Sustainability and Successful Implications, New York Institute of Technology, New York, pp. 75-94.

Day, G., (1994), "The Capabilities of Market-Driven Organisations", Journal of Marketing, Vol. 58 No. 4, pp. 37-52.

Day, G. and Fahey, L., (1988), "Valuing Market Strategies", Journal of Marketing, Vol. 52 No. 3, pp. 45-57.

Deegan, C., (2000), Financial Accounting Theory, McGraw-Hill, Sydney.

Deegan, C. and Gordon, B., (1996), "A Study of the Environmental Disclosure Policies of Australian Corporations", Accounting and Business Research, Vol. 26 No. 3, pp. 187-199.

Eccles, R. G. and Serafeim, G., (2011), "Accelerating the Adoption of Integrated Reporting", in F. de Leo and M. Vollbracht, CSR Index, Innovation Publishing, Wheeling, pp. 70-92.

Edvinsson, L., (1997), "Developing Intellectual Capital at Skandia", Long Range Planning, Vol. 30 No. 3, pp. 366-373. 
Edvinsson, L., (2000), "Some Perspectives on Intangibles and Intellectual Capital 2000”, Journal of Intellectual Capital, Vol. 1 No. 1, pp. 12-16.

Edvinsson, L. and Malone, M. S., (1997), Intellectual Capital: Realizing Your Company's True Value by Finding its Hidden Roots, Harper Collins, New York.

Fincham, R. and Roslender, R., (2003), The Management of Intellectual Capital and its Implications for Business Reporting, The Institute of Chartered Accountants of Scotland, Edinburgh.

Freeman, R. E., (1984), Strategic Management: A Stakeholder Approach, Pitman, Boston.

Freeman, R. E., Wicks, A. C. and Parmar, B., (2004), "Stakeholder Theory and the Corporate Objective Revisited", Organisation Science, Vol. 15 No. 3, pp. 364-369.

Garcia-Ayuso, M., (2003), "Factors Explaining the Inefficient Valuation of Intangibles", Accounting, Auditing and Accountability Journal, Vol. 16 No.1, pp. 57-69.

Goh, P. C., (2005), "Intellectual Capital Performance of Commercial Banks in Malaysia", Journal of Intellectual Capital, Vol. 6 No. 3, pp. 385-386.

Grant, R. M., (1991), "The Resource-Based Theory of Competitive Advantage: Implications for Strategy Formulation", California Management Review, Vol. 33 No. 3, pp.14-35.

Gray, R., Kouhy, R. and Lavers, S., (1995), "Corporate Social and Environmental Reporting: A Review of the Literature and a Longitudinal Study of UK Disclosure", Accounting, Auditing and Accountability Journal, Vol. 8 No.2, pp. 47-77.

Grimaldi, M., Cricelli, L. and Rogo, F., (2013), "A Theoretical Framework for Assessing Managing and Indexing the Intellectual Capital”, Journal of Intellectual Capital, Vol. 14 No.4, pp.501-521.

Guthrie, J., Petty, R. and Johanson, U., (2001), "Sunrise in the Knowledge Economy: Managing, Measuring and Reporting Intellectual Capital", Accounting, Auditing and Accountability Journal, Vol. 14 No. 4, pp. 365-384. 
Guthrie, J., Petty R., Yongvanich, K. and Ricceri, F., (2004), "Using Content Analysis as a Research Method to Inquire into Intellectual Capital Reporting”, Journal of Intellectual Capital, Vol. 5 No. 2, pp. 282-293.

Hsu, Y. H. and Fang, W., (2009), "Intellectual Capital and New Product Development Performance: The Mediating Role of Organizational Learning Capability", Technological Forecasting and Social Change, Vol. 76 No. 5, pp. 664-677.

Iazzolino, G. and Laise, D., (2013), "Value Added Intellectual Coefficient (VAIC): A Methodological and Critical Review", Journal of Intellectual Capital, Vol. 14 No. 4, pp.547-563.

Johanson, U., Skoog, M., Backlund, A. and Almqvist, R., (2006), "Balancing Dilemmas of the Balanced Scorecard", Accounting, Auditing and Accountability Journal, Vol. 19 No. 6, pp. 842-857.

Joshi, M., Singh Ubha, D. and Sidhu, J., (2010), "Reporting Intellectual Capital in Annual Reports from Australian S/W \& I/T Companies", Journal of Knowledge Management Practice, Vol. 11 No. 3, pp. 1-3.

Kaplan, R. S. and Norton, D. P., (1992), "The Balanced Scorecard: Measures that Drive Performance", Harvard Business Review, Vol. 70 No. 1, pp 71-79.

Kaplan, R. S. and Norton, D. P., (1993), "Putting the Balanced Scorecard to Work", Harvard Business Review, Vol. 71 No. 5, pp. 134-147.

Kaplan, R. S. and Norton, D. P., (1996), "Using the Balanced Scorecard as a Strategic Management System", Harvard Business Review, Vol. 74 No. 1, pp. 75-85.

Kaplan, R. S. and Norton, D. P., (2001), The Strategy-Focused Organization: How Balanced Scorecard Companies Thrive in the New Business Environment, Harvard Business School Press, Boston.

Kong, E., (2010), "Analyzing BSC and IC's Usefulness in Non-Profit Organizations", Journal of Intellectual Capital, Vol. 11 No. 3, pp. 284304.

Lee, L. L. and Guthrie, J., (2010), "Visualising and Measuring Intellectual Capital in Capital Markets: A Research Method", Journal of Intellectual Capital, Vol. 11 No. 1, pp. 4-22. 
Luo, X. and Donthu, N., (2006), "Marketing's Credibility: A Longitudinal Investigation of Marketing Communication Productivity and Shareholder Value", Journal of Marketing, Vol. 70 No. 4, pp.70-91.

Luthy, D. H., (1998), "Intellectual Capital and its Measurement", Proceedings of 2nd Asian Pacific Interdisciplinary Research in Accounting (APIRA) Conference, Osaka, Japan.

Martin-de-Castro, G., Delgado-Verde, M., Lopez-Saez, P. and NavasLopez, J. E., (2011), "Towards 'An Intellectual Capital-Based View of the Firm: Origins and Nature"', Journal of Business Ethics, Vol. 98 No. 4, pp. 649-662.

Marr, B., Gray, D. and Neely, A., (2003), "Why do Firms Measure their Intellectual Capital?", Journal of Intellectual Capital, Vol. 4 No. 4, pp. 441-464.

McVea, J. H. and Freeman, R. E., (2005), "A Names-and-Faces Approach to Stakeholder Management", Journal of Management Inquiry, Vol. 14 No. 1, pp. 57-69.

MERITUM, (2002), Guidelines for Managing and Reporting on Intangibles (Intellectual Capital Report), European Union, Brussels.

Mouritsen, J., (2006), "Problematising Intellectual Capital Research: Ostensive Versus Performative IC", Accounting, Auditing and Accountability Journal, Vol. 19 No. 6, pp. 820-841.

Mouritsen, J., Bukh, P. N., Flagstad, K., Thorbjørnsen, S., Johansen, M. R., Kotnis, S., Larsen, H. T., Nielsen, C., Kjærgaard, I., Krag, L., Jeppesen, G., Haisler, J. and Stakemann, B., (2003), Intellectual Capital Statements - The New Guideline, Danish Ministry of Science, Technology and Innovation, Denmark.

Mouritsen, J., Bukh, P. N., Larsen H. T. and Johansen, M. R., (2002), "Developing and Managing Knowledge through Intellectual Capital Statements", Journal of Intellectual Capital, Vol. 3 No. 1, pp. 10-29.

Mouritsen, J., Bukh, P. N. and Marr, B., (2004), "Reporting on Intellectual Capital: Why, What and How?", Measuring Business Excellence, Vol. 8 No. 1, pp. 46-54.

Mouritsen, J, Larsen, H. T. and Bukh, P. N., (2001), "Valuing the Future: Intellectual Capital Supplements at Skandia", Accounting, Auditing and Accountability Journal, Vol. 14 No. 3, pp. 399-422. 
Nielsen. C., Bukh, P. N., Mouritsen, J., Johansen M. R. and Gormen, P., (2006), "Intellectual Capital Statements on their Way to the Stock Exchange: Analyzing New Reporting Systems", Journal of Intellectual Capital, Vol. 7 No. 2, pp. 221-240.

Palacios, T. M. B. and Galvan, R. S., (2007), "Intangible Measurement Guidelines: A Comparative Study in Europe", Journal of Intellectual Capital, Vol. 8 No. 2, pp. 192-204.

Petty, R. and Guthrie, J., (2000), "Intellectual Capital Literature Review: Measurement, Reporting and Management", Journal of Intellectual Capital, Vol. 1 No. 2, pp. 155-176.

Pulic, A., (1998), "Measuring the Performance of Intellectual Potential in Knowledge Economy", Proceedings of 2nd World Congress on Intellectual Capital, Hamilton.

Pulic, A., (2000), "VAIC - An Accounting Tool for IC Measurement", International Journal of Technology Management, Vol. 20 No. 5-8, pp. 702-714.

Pulic, A., (2004), "Intellectual Capital: Does it Create or Destroy Value?", Measuring Business Excellence, Vol. 8 No. 1, pp. 62-68.

Ratnatunga, J., (2002), "The Valuation of Capabilities: A New Direction from Management Accounting Research", Journal of Applied Management Accounting Research, Vol. 1 No. 1, pp. 1-15.

Ratnatunga, J. and Ewing, M., (2005), "The Brand Capability Value of Integrated Marketing Communication (IMC)", Journal of Advertising, Vol. 34 No. 4, pp. 25-40.

Ratnatunga, J., Gray, N. and Balachandran, K. R., (2004), "CEVITA: The Valuation and Reporting of Strategic Capabilities", Management Accounting Research, Vol. 15 No. 1, pp. 77-105.

Riahi-Belkaoui, A., (2003), "Intellectual Capital and Firm performance of US Multinational Firms: A Study of the Resource-Based and Stakeholder Views", Journal of Intellectual Capital, Vol. 4 No. 2, pp. 215-226.

Roslender, R. and Fincham, R., (2001), "Thinking Critically about Intellectual Capital Accounting", Accounting Auditing and Accountability Journal, Vol. 14 No. 4, pp. 311-329. 
Roslender, R. and Stevenson, J., (2009), “Accounting for People: A Real Step Forward or More a Case of Wishing and Hoping?", Critical Perspectives on Accounting, Vol. 20 No. 7, pp. 855-869.

Sahay, A. and Pillai, A., (2009), "Differential Impact of Advertising and Distribution Expenditure on Tobin's Q: A Perspective from Listed Firms in India", Journal of Indian Business Research, Vol. 1 No. 2-3, pp.77-94.

Seetharaman, A, Low, K. L. T. and Saravannan, A. S., (2004), "Comparative Justification on Intellectual Capital", Journal of Intellectual Capital, Vol. 5 No. 4, pp. 522-538.

Sennetti, J. T., Kim, C. and Sellani, R. J., (2004), "Measuring the Effect of Investment in Intellectual Capital", Journal of Applied Management and Entrepreneurship, Vol. 9 No. 2, pp. 82-96.

Singleton-Green, B. and Hodgkinson, R., (2009), Developments in New Reporting models, Financial Reporting Faculty, The Institute of Chartered Accountants in England and Wales, London.

So, M., (2014), The Voluntary Disclosure of Intellectual Capital by Hong Kong Companies: A Descriptive and Normative Study, PhD Dissertation, University of South Australia.

Stahle, P., Stahle, S. and Aho, S., (2011), "Value Added Intellectual Coefficient (VAIC): A Critical Analysis", Journal of Intellectual Capital, Vol. 12 No. 4, pp. 531-551.

Stern, J. M., Stewart, G. B. and Chew, D. H., (1995), "The EVA Financial Management System", Journal of Applied Corporate Finance, Vol. 8 No. 2, pp. 32-46.

Stewart, T. A., (1997), Intellectual Capital: The New Wealth Organisations, Nicholas Brealey Publishing Limited, London.

Stewart, T. A., (2001), The Wealth of Knowledge: Intellectual Capital and the Twenty-First Century Organisation, Doubleday Publishing, New York.

Sveiby, K. E., (1997), “The Intangible Assets Monitor", Journal of Human Resource Costing and Accounting, Vol. 2 No. 1, pp. 73-97.

Sveiby, K. E., (2001), "Acknowledge Based Theory of the Firm to Guide in Strategy Formulation", Journal of Intellectual Capital, Vol. 2 No. 4, pp.344-358. 
Sveiby, K. E., (2010), "Methods for Measuring Intangible Assets", available at https://www.sveiby.com/files/pdf/intangiblemethods.pdf [Assessed 17 September 2018].

Tayles, M., Bramley, A., Adshead, N. and Farr, J., (2002), "Dealing with the Management of Intellectual Capital: The Potential Role of Strategic Management Accounting", Accounting, Auditing and Accountability Journal, Vol. 15 No. 2, pp. 251-267.

Teece, D.J., Pisano, G. and Shuen, A., (1997), "Dynamic Capabilities and Strategic Management", Strategic Management Journal, Vol. 18 No. 7, pp.509-533.

Tobin, J., (1969), "A General Equilibrium Approach to Monetary Theory”, Journal of Money, Credit and Banking, Vol. 1 No. 1, pp. 15-29.

Tseng, C. and Goo, J., (2005), "Intellectual Capital and Corporate Value in an Emerging Economy: Empirical Study of Taiwanese Manufacturers", $R \& D$ Management, Vol. 35 No. 2, pp.187-201.

Vergauwen, P. G. M. C. and van Alem, F. J. C., (2005), "Annual Report IC Disclosures in the Netherlands, France and Germany", Journal of Intellectual Capital, Vol. 6 No. 1, pp. 89-104.

Whiting, R. and Miller, J., (2008), "Voluntary Disclosure of Intellectual Capital in New Zealand Annual Reports and the Hidden Value", Journal of Human Resource Costing and Accounting, Vol. 12 No. 1, pp. 26-50.

Wu, A., (2005), "The Integration between Balanced Scorecard and Intellectual Capital", Journal of Intellectual Capital, Vol. 6 No. 2, pp. 267-284.

Yang, J., Brashear, T. G. and Asare, A., (2015), "The Value Relevance of Brand Equity, Intellectual Capital and Intellectual Capital Management Capability", Journal of Strategic Marketing, Vol. 23 No. 6, pp. 543-559. 